\title{
ALTERNATIF MODEL KEPEMIMPINAN PADA ERA GLOBALISASI
}

\author{
Nida Hasanati \\ Fakultas Psikologi Universitas Muhammadiyah Malang \\ Email: adin.hasanati@yahoo.co.id
}

\begin{abstract}
The current global situation is characterized by a variety of leadership requires a paradigm change in accordance with change itself. Leaders who have superior characteristics and exhibit adaptive behaviors to change, leaders are able to capture the phenomenon in the leadership and understand who the followers, so the process of directing, guiding, motivating and preparing future leaders can be achieved with good. This paper intends to provide an overview of the changes in the present paradigm, trying to see the similarities between transformational leadership as the present leadership with recognized leadership rooted in Indonesian society and initiated by Ki Hajar Dewantara. In addition it also presented about followership, which actually integrates with the leadership itself, thus the possibility of achieving success in the lead is not a difficult thing.
\end{abstract}

Situasi global yang saat ini dicirikan dengan berbagai perubahan paradigma membutuhkan kepemimpinan yang sesuai dengan perubahan itu sendiri. Pemimpin yang memiliki ciri-ciri yang unggul serta menunjukkan perilaku yang adaptif terhadap perubahan, mampu menangkap fenomena di lingkungan kepemimpinannya serta memahami siapa yang menjadi pengikutnya. Tulisan ini bermaksud memberikan gambaran tentang perubahan paradigma pada masa sekarang, mencoba melihat kesamaan antara konsep kepemimpinan transformasional sebagai kepemimpinan masa sekarang dan konsep kepemimpinan yang dikenal berakar dari masyarakat Indonesia yang digagas oleh $\mathrm{Ki}$ Hadjar Dewantara. Selain itu dipaparkan pula tentang followership atau kepengikutan, yang sebenarnya menyatu dengan proses kepemimpinan itu sendiri, dengan demikian kemungkinan tercapainya keberhasilan dalam memimpin bukan hal yang sulit.

Situasi global masa kini menunjukkan perubahan paradigma lama dan muncul paradigma baru dalam pengelolaan sumber daya manusia di organisasi yang sangat perlu dicermati oleh berbagai pihak yang terkait di dalamnya. Daniel C. Kielson (Safaria, 2004) memaparkan adanya perubahan-perubahan tersebut. Pertama, penghargaan akan stabilitas menuju penghargaan akan perubahan. Di sini kemapanan yang diidamkan oleh semua orang berubah menjadi kondisi yang tidak bisa diramalkan dari waktu ke waktu dan harus disikapi secara positif. Situasi yang berubah dari waktu ke waktu begitu cepat terjadi sehingga setiap orang, setiap pemimpin harus selalu siap menghadapi perubahan dan akhirnya mengatakan bahwa perubahan adalah yang biasa, perubahan tidak perlu disikapi dengan berlebihan .

Kedua, kontrol ke pemberdayaan. Perlakuan yang terlalu kaku dan ketat tidak hanya memicu masalah yang tidak diinginkan, tapi juga bisa menghancurkan motivasi dan inovasi yang diperlukan untuk pengembangan organisasi. Sebaliknya, adanya pemberdayaan yang memungkinkan semua anggota berpartisipasi akan menumbuhkan rasa memiliki dan komitmen pada organisasi.

Ketiga, kompetisi menuju kolaborasi. Persaingan antar individu dalam organisasi kadang memotivasi sebagian anggota tapi berdampak negatif pada sebagian orang lain yang merasa kalah. Karena itu dibutuhkan perasaan menang bersama melalui kerja secara tim.

Keempat, penekanan pada produk dan mesin menuju hubungan. Dari melakukan 
pemisahan secara mutlak antara bagian yang satu dengan yang lain diganti dengan mencoba memahami suatu fenomena dengan menyeluruh (holistic).

Kelima, keseragaman menuju keanekaragaman :spesialisasi dan keseragaman kurang relevan lagi dengan semakin beragamnya anggota organisasi karena dunia sudah terbuka yang mengakibatkan semakin variatifnya anggota organisasi. Keanekaragaman akan memunculkan sikap fleksibilitas dan adaptif dalam menghadapi benturan yang banyak terjadi

Konsekuensi yang muncul akibat adanya perubahan paradigma adalah adanya kebutuhan untuk menemukan pemimpin yang bisa menyikapi secara positif kondisikondisi tersebut sehingga bisa membawa organisasi bersama anggota untuk beradaptasi dengan baik. Yacobs dan Jacques (Yukl, 2008) mengartikan kepemimpinan sebagai proses mempengaruhi terhadap usaha yang dilakukan secara berkelompok dan membuat orang bersedia untuk melakukan usaha yang diinginkan dalam rangka mencapai tujuan organisasi.

Teori kepemimpinan terdiri dari dua yaitu teori sifat dan teori kepribadian perilaku. Teori sifat berupaya mengidentifikasikan karakreristik khas (fisik, mental dan kepribadian) yang dikaitkan dengan keberhasilan pemimpin. Teori ini didasarkan pada asumsi bahwa beberapa orang merupakan pemimpin alamiah dan dianugerahi beberapa ciri yang tidak dipunyai orang lain, seperti energi yang tiada habis-habisnya, intuisi yang mendalam, pandangan masa depan yang luar biasa dan kekuatan persuasif yang tidak tertahankan (Rivai, 2003).

Menurut Levinson ( 2006$)$, karakteristik pemimpin yang baik adalah :

1. Thinking (kemampuan berpikir)

a. Kemampuan berpikir abstrak, yaitu mampu membuat konsep, m e n g r g a n i s a i d a n mengintegrasikan data yang berbeda ke dalam kerangka referensi yang sama b. Toleransi terhadap ambiguitas, yaitu dapat mengatasi kekacauan sampai mencapai kejelasan

c. Cerdas, yang berarti mempunyai kapasitas tidak hanya abstrak tapi juga kemampuan praktis

d. Membuat keputusan, yang berarti mengetahui apa yang harus dilakukan.

2. Feeling andinterrelationship

a. Memiliki otoritas, yaitu mempunyai perasaan bahwa dia memiliki peran sebagai bos (pemimpin)

b. Aktif, yaitu memiliki semangat dalam mengatasi masalah dan kebutuhan organisasi

c. Prestasi, yaitu orientasi ke arah keberhasilan organisasi dari pada kekuasaan pribadi

d. Kepekaan (sensitive)

e. Keterlibatan (involvement), yaitu melihat diri sendiri karena berpastisipasi sebagai anggota organisasi

f. Matang (maturation), yang berarti mempunyai hubungan yang baik dengan figure otoritas

g. Bebas, yaitu menerima keburuhan ketergantungan dari orang lain sebagaimana dirinya

h. Kemampuan berartikulasi, yaitu membuat impresi atau kesan yang bagus

i. Stamina, yang berarti memiliki energi fisik sebaik energi mental

j. Menyesuaikan diri, mengelola stres dengan baik

k. Memiliki sense humor yang baik, tidak terlalu serius

3. Outward behavior characteristic (ciriciri perilaku keluar)

a. Visi, yaitu menjelaskan tentang kemajuan dalam kehidupan dan karirnya, sebaik organisasi divmana dia ada

b. Tekun, yaitu mampu mengatasi tugas dan melepas dari kesulitan yang dihadapi

c. Integritas, yaitu memiliki sistem nilai yang sudah terbentuk dengan baik, 
yang sudah diuji dalam berbagai cara di masa lalu

d. Tanggung jawab sosial, yaitu menghargai perlunya untuk mengasumsikan kepemimpinan yang berkaitan dengan tanggung jawab itu

Karakteristik ideal yang diharapkan dimiliki oleh pemimpin agaknya sulit untuk dipenuhi secara keseluruhan karena seorang manusia diciptakan memiliki kelebihan dan kekurangan masing-masing. Oleh karena itu sulit juga menemukan seorang pemimpin yang sempurna. Efektif tidaknya pemimpin tidak hanya tergantung dari sifat pemimpin belaka, namun peran dari bawahan sangat mendukung kepemimpinan itu berlangsung dan juga situasi dan kondisi yang sedang terjadi Salah satu modal yang dimiliki pemimpin dalam upaya mempengaruhi orang lain (bawahan) adalah power (kekuasaan), dengan power tersebut pemimpin legal memiliki otoritas mutlak untuk memerintah bawahan dan bawahan tidak bisa menentang perintah tersebut. Masalahnya, apakah perintah tersebut dilakukan dengan senang hati atau dengan terpaksa, inilah yang bisa menyebabkan hasil kerja bawahan berbeda dengan yang diharapkan pleh pemimpin.

Bagaimana orang bisa mempengaruhi orang lain atau suatu kelompok diperlukan semacam power (kekuasaan), yang dipengaruhi oleh sumber kekuasaan yang dimiliki oleh individu atau pemimpin. Menurut French dan Raven (Yukl, 2007) terdapat lima sumber kekuasaan, yaitu:

1. Reward power : bawahan patuh agar dapat memperoleh imbalan yang diyakini dimiliki pemimpin

2. Coercive power: bawahan patuh agar dapat menghindari hukuman yang diyakini dimiliki oleh pemimpin

3. Legitimate power: bawahan patuh karena ia percaya bahwa pemimpin tersebut mempunyai hak untuk meminta dan bawahan mempunyai kewajiban untuk mematuhinya

4. Expert power: bawahan patuh karena ia percaya bahwa pemimpin mempunyai pengetahuan mengenai cara yang terbaik untuk melakukan sesuatu

5. Referent power: bawahan patuh karena ia mengagumi atau mengidentifikasikan dirinya dengan pemimpin dan ingin diterima oleh pemimpin.

Dari hasil penelitian ditemukan bahwa pemimpin yang memiliki expert power dan referent power mempunyai anak buah (bawahan) yang lebih termotivasi dan lebih puas, menunjukkan tingkat absensi yang rendah dan kinerja yang bagus (Yukl, 2007).Mengapa dua sumber ini dikatakan lebih mengena pada bawahan? Hal ini terjadi karena pada dasarnya anggota lebih menghargai kekuasaan yang bersumber langsung dan melekat pada diri pemimpin yang membuat mereka percaya dan kagum akan keahlian maupun kepribadiannya. Sedangkan yang lain, lebih bersifat sementara dan seringkali tidak dibarengi dengan kualitas kepribadian maupun keahlian yang memadai untuk memimpin.

Dalam teori kepemimpinan yang berkembang terdapat model kepemimpinan yang berlandaskan cenderung menggunakan referent power dan expert power yang dikenal dengan kepemimpinan transformasional dan kepemimpinan transaksional yang didasari reward power dan coercive power. Kepemimpinan transformasional dimaknai sebagai kepemimpinan yang melibatkan perubahan dalam organisasi, sedangkan kepemimpinan transaksional melibatkan suatu proses pertukaran (exchange proccess) antara di mana para pengikut mendapatkan imbalan yang segera dan nyata untuk melakukan perintah-perintah pemimpin (Bass,1985; Burn, dalam Locke, 1997).

Menurut Bass (1985), seorang pemimpin dapat mentransformasikan bawahannya melalui empat cara:

1. Idealized Influence (kharisma): mempunyai pengetahuan yang luas di bidangnya, membangkitkan kepercayaan dan memberi teladan dalam hal sikap, perilaku, prestasi maupun komitmen kepada bawahannya

2. Inspirational Motivation: menantang dan memberikan inspirasi pada bawahan 
dengan melatih kepekaan dan menciptakan kegembiraan dalam menyelesaikan pekerjaannya, membangkitkan semangat, optimisme

3. Intellectual Stimulation: mendorong bawahan memunculkan ide-ide baru dan inovatif atas masalah yang dihadapi

4. Individualized consideration: memberikan perhatian sesuai dengan kebutuhan individu untuk berprestasi dan berkembang.

Pemimpin yang menerapkan gaya transformasional akan membawa dampak positif baik untuk organisasi maupun bawahannya. Iklim dan akibat yang diperoleh bawahan adalah meningkat motivasi kerja, antusiasme, komitmen, kepuasan kerja, kesejahteraan dan kesehatan bawahan. Hal ini dibuktikan dengan bebeapa peneliti yang berminat mempelajarinya, seperti Emerry dan Barker (2007) yang menemukan bahwa kepemimpinan transformasional mempunyai korelasi yang tinggi dengan komitmen organisasi dan kepuasan kerja pada customer contact personnel. Selain itu, Logomarsino dan Cardona (2003) membuktikan juga adanya hubungan antara kepemimpinan transformasional dengan komitmen organisasi (growth organizational commitment dan normative commitment ) pada karyawan di bidang kesehatan. Penulis juga menemukan adanya hubungan yang cukup kuat antara kepemimpinan transformasional dengan komitmen afektif pada karyawan perusahaan gula (Hasanati, 2002).

Gaya kepemimpinan yang berbeda yang juga dimunculkan Burn, yaitu gaya kepemimpinan transaksional. Burn (1978) menerangkan keterkaitan antara konsep kepemimpinan transformasionaltransaksional dengan teori tingkat kebutuhan dari Maslow, dijelaskan bahwa kebutuhan karyawan level rendah seperti kebutuhan fisik, kebutuhan rasa aman, dan diterima oleh orang lain dipenuhi dengan kepemimpinan transaksional, sedang untuk memenuhi kebutuhan karyawan dengan level lebih tinggi yaitu harga diri dan aktualisasi diri hanya bisa dipenuhi oleh gaya kepemimpinan transformasional.
Kepemimpinan transaksional menurut Bass (Locke, 1998) dikatakan sebagai pertukaran imbalan-imbalan untuk mendapatkan kepatuhan melalui (a) contingent reward : melakukan proses pertukaran dengan bawahan dan (b) Management by exception (manajemen seperlunya). Management by exception ini terdiri atas:

1. Management by exception (active), memantau secara terus menerus kinerja bawahan untuk mengantisipasi kesalahan-kesalahan sebelum mempunyai problem dan segera melakukan tindakan koreksi bila terjadi penyimpangan

2. Management by exception (passive): melakukan intervensi jikan standard tidak tercapai, dan dilakukan akhir penyelesaian.

Apabila dibandingkan dengan kepemimpinan transformasional, banyak penelitian yang menunjukkan kurang adanya hubungan antara kepemimpinan transaksional dengan komitmen organisasi. Jika ada korelasi antara kepemimpinan transaksional dengan komitmen organisasi, maka korelasi lebih kuat adalah antara kepemimpinan transaksional dan continuance commitment daripada bentuk komitmen yang lain. Mengapa komitmen di sini merupakan hal yang penting dalam era globalisasi, karena tantangan yang semakin berat yang dihadapi oleh suatu organisasi akibat adanya perubahan-perubahan tersebut tidak akan bisa berjalan baik apabila karyawan tidak mempunyai komitmen yang kuat. Ini dapat ditemukan bahwa komitmen organisasi mempunyai korelasi yang positif dengan hasil yang diinginkan organisasi seperti kinerja yang tinggi, rendahnya tingkat keluar masuk karyawan dan tingkat ketidak hadiran karyawan yang rendah (Miner, 1993).

Sebagian besar studi tentang kepemimpinan saat ini masih berorientasi pada teori-teori dari Barat, seperti contohcontoh di atas, walaupun itu juga tidak buruk. Namun begitu bangsa Indonesia yang besar tentunya tidak seharusnya selalu mendewadewakan teori yang berakar dari budaya kita yang berbeda. Sebenarnya di Indonesia ada 
seorang tokoh nasional di bidang pendidikan yang melontarkan suatu acara tentang bagaimana pemimpin seharusnya bertindak, tokoh yang mendirikan perguruan taman siswa yang digagas paada tahun. Meskipun ajaran itu lebih dulu dimaksudkan untuk memandu bagaimana seorang guru berperan dan bertindak di antara anak didiknya. Namun pada kenyataannya teori itu bisa saja diterapkan dalam dunia organisasi, pandangan ini sangat terkenal dengan tiga prinsip utama seperti yang dijelaskan di bawah ini. Hal ini juga diakui oleh Djamuludin Ancok seorang ahli di bidang kepemimpinan yang mengatakan bahwa kita bangsa Indonesia sudah memiliki konsep kepemimpinan yang bagus dan berpotensi untuk dikembangkan, dan salah satunya menyebut ajaran dari Ki Hadjar Dewantoro (Pamudji, 1995 ). Ki Hadjar Dewantoro menjelaskan bahwa pemimpin seharusnya mengikuti tiga prinsip yaitu:

1. Ing ngarso sung tulodho. Seorang pemimpin harus mampu, melalui sikap dan perbuatannya, menjadikan dirinya pola anutan dan ikutan orang yang dipimpinnya.

2. Ing madyo mangun karso. Seorang pemimpin harus mampu membangkitkan semangat berswakarsa dan berkreasi pada orang-orang yang dibimbingnya

3. Tut wuri handayani. Seorang pemimpin harus mampu mendorong anggotanya agar berani berjalan di depan dan sanggup bertanggung jawab.

Apabila kita mencermati apa yang diuraikan oleh Ki Hadjar Dewantoro dan memahami gaya kepemimpinan Transformasional, maka kita menemukan prinsip yang hampir mendekati mirip. Oleh karena itu penulis mencoba mendekatkan ke dua tokoh tersebut seperti yang tercantum di bawah ini

\begin{tabular}{|l|c|}
\hline $\begin{array}{l}\text { Kepemimpinan } \\
\text { transformasional }\end{array}$ & $\begin{array}{l}\text { Kepemimpinan Menurut } \\
\text { Dewantara }\end{array}$ \\
\hline $\begin{array}{l}\text { Idealized Influence } \\
\text { (kharisma) }\end{array}$ & Ing Ngarso Sung tulodho \\
\hline Inspirational Motivation & Ing Madyo Mangun Karso \\
\hline Intellectual Stimulation & Ing Madyo Mangun Karso \\
\hline Individualized consideration & Tut Wuri handayani \\
\hline
\end{tabular}

Karakteristik pemimpin yang memiliki kharisma menunjukkan perilaku-perilaku yang patut dicontoh oleh bawahan, misalnya kebiasaan kerja keras dan disiplin pada setiap hari. Dengan perilaku yang tampak tersebut bawahan dihadapkan pada contoh atau teladan yang baik. Seperti ciri "Ing ngarso sung tulodho", yang menekankan pentingnya pemimpin memberikan contoh baik bagi lingkungan sekitarnya terutama bawahan. Dengan demikian pemimpin mampu membangkitkan kepercayaan dan memberi teladan dalam hal sikap, perilaku, prestasi maupun komitmen kepada bawahannya

Ciri Inspirational Motivation dan Intellectual Stimulation sepadan dengan prinsip "Ing madyo mangun karso" di mana pemimpin menantang dan memberikan inspirasi pada bawahan dengan melatih kepekaan dan menciptakan kegembiraan dalam menyelesaikan pekerjaannya, membangkitkan semangat, optimisme, mendorong bawahan memunculkan ide-ide baru dan inovatif atas masalah yang dihadapi. Secara umum diharapkan pemimpin yang demikian memberikan motivasi ketika berada di tengah-tengah bawahannya, memberikan solusi permasalahan yang tidak konvesional dan mencoba memberikan alternative yang mungkin belum terpikirkan oleh bawahan. Kegagalan yang dialami tidak dianggap sebagai sesuatu yang buruk namun justru mempunyai nilai yang positif untuk melanjutkan langskah berikutnya, dengan demikian bawahan akan tetap optimis meskipun banyak dihadang oleh hambatanhambatan.

Sementara itu ciri yang lain, Individualized consideration yang memiliki ciri memberikan perhatian sesuai dengan kebutuhan individu untuk berprestasi dan berkembang hampir setara dengan "Tut wuri Handayani" yang dimaknai bahwa pemimpin mampu mendorong anggotanya agar berani berjalan di depan dan sanggup bertanggung jawab. Dengan mengetahui secara individual tentang kelebihan dan kekurangan bawahan, pemimpin memberi kesempatan bawahan supaya bawahan 
berani melakukan rencana-rencana yang telah dibuat dan mencapai prestasi yang diharapkan.

Adanya keterkaitan atau kesamaan yang ada pada pada ke dua pemikiran dari tokoh yang berbeda dan budaya yang berbeda menunjukkan bahwa setiap bagian dari negara di dunia memiliki potensi yang berakar dari budaya lingkungan dan potensial untuk dikembangkan menjadi teori yang bersifat indigeneus sehingga akan lebih tepat diaplikasikan dalam konteks masyarakat Indonesia.

Proses kepemimpinan yang dilakukan di setiap organisasi, baik di institusi pemerintah, pemimpin perusahaan maupun di organisasi kemasyarakatan tidak lepas dari peran pengikut (bawahan atau anggota). Oleh karena itu followership (kepengikutan), merupakan sesuatu yang cukup penting untuk dibahas. Definisi followership dapat dipahami melalui penjelasan tentang followership sebagai suatu peran yang interaktif. Menurut Riggio, Chaleff, dan Lipman-Blumen (2008), salah satu Orientasi Peran adalah memandang followership sebagai suatu peran interaktif yang melengkapi dan mendukung peran kepemimpinan. Keberhasilan suatu kepemimpinan tidak bisa lepas dari peran bawahan karena sebagian besar pekerjaan dalam suatu organisasi dilakukan oleh bawahan. Bawahan yang efektif mempunyai ciri-ciri:

1. Memperlihatkan pengetahuan tentang pekerjaan dan kompetensi pada tugastugas pekerjaan

2. Membangun kolaborasi dan hubungan yang suportif denga rekan sekerja dan pemimpin.

3. Mempertahankan dan mendukung pemimpin di depan pihak lain

4. Membantu pemimpin menghindari kesalahan yang merugikan dengan percaya diri dan cara yang tidak emotional

5. Memperlihatkan sikap yang tepat untuk organisasi ( termasuk bicara yang pantas, pakaian yang tepat dan beretika)

6. Menunjukkan perhatian dengan bersikap ramah
7. Memperlihatkan keinginan untuk berpartisipasi di dalam perubahanperubahan yang diperlukan

Karakteristik bawahan yang efektif tidak selamanya dimiliki oleh seseorang yang berada pada posisi dipimpin orang lain, sebagai manusia yang memiliki kelemahan dan kelebihan setiap bawahan kemungkinan sulit untuk memenuhi gambaran utuh yang diinginkan oleh pemimpin pada umumnya seperti yang dijelaskan di atas.

Hal lain yang perlu diperhatikan oleh pemimpin adalah berbagai tipe bawahan yang mungkin menjadi bawahannya, di mana setiap tipe akan mempengaruhi bagaimana seharusnya memberikan perlakuan. Ke 5 tipe tersebut menurut Riggio, Chaleff, dan Lipman-Blumen (2008) adalah :

1. The sheep (domba): domba adalah pasif dan mencari pemimpin yang berpikir untuk mereka dan memotivasi mereka. Jika anda adalah bos dan mobil anda adalah cara anda dalam bekerja, dan anda bepikir tentang apa yang pekerja lakukan dan bagaimana anda melakukan itu, maka anda berhubungan dengan domba.

2. The yes-people: yes-people adalah positif, selalu di samping pemimpin tetapi tetap mencari pemimpin untuk berpikir, mengarahkan dan menjelaskan visi. Jika pemimpin bertanya kepada mereka apa yang dilakukan, mereka tidak memperoleh energi, dan mereka akan tampil dengan itu. Ketika mereka selesai , mereka akan kembali ke pemimpin, dan bertanya ' apa yang saya lakukan selanjutnya?'

3. The alienated (menjauhkan diri) : pengikut yg teralienasi berpikir utk dirinya sendiri, tetapi mereke memiliki banyak energi yang negative. Mereka tidak menemukan solusi berikutnya, tapi bersikap skeptis, sinis tentang rencana tindakan saat ini. Mereka memiliki energi, mereka dapat berpikit untuk mereka sendiri, mereka cerdas, tetapi mereka tidak bergerak kevarah yang positif.

4. Pragmatis: pengikut yang pragmatis 
berdiri pada batas pagar dan melihat kemana angin bertiup. Mereka melihat diri mereka sendiri sebagai pemelihara status quo. Mereka melakukan apa yang mereka harus dilakukan untuk bertahan hidup.

5. The star followers : pengikut-pengikut bintang berpikir untuk diri mereka sendiri, sangat aktif, dan mempunyai energy yang positif. Mereka tidak menerima keputusan pemimpin tanpa memiliki kebebasan evaluasi. Jika mereka setuju dengan pemimpin, mereka memberikan dukungan penuh. Jika mereka tidak setuju mereka menentang pemimpin, menawarkan alternative yang konstruktif yang akan membantu pemimpin dan organisasi mendapatkan apa yang diinginkan. Star follower sering dikatakan sebagai tangan kanan pemimpin.

Keadaan yang ideal dalam proses kepemimpinan sangat sulit terjadi, dengan pemimpin yang memiliki semua kualitas yang baik, dengan pengikut yang efektif menjalankan peran kepengikutannya serta pengikut dengan tipe bintang. Namun demikian terdapat suatu model kepemimpinan yang memperhitungkan faktor pemimpin dan faktor bawahan.

Kepemimpinan transformasional merupakan model kepemimpinan yang pertama menentukan keberhasilan pemimpin diukur dari mampu tidaknya mengembangkan potensi pengikutpengikutnya, setidaknya mempersiapkan pengikut menjadi seorang pemimpin (Riggio, Chaleff, \& Lipman-Blumen, 2008). Pemimpin transformasional digambarkan oleh Burns sebagai visioner, merangsang intelektual, akhlak yang tinggi, kharismatik, dan memperhatikan kebutuhan pengikut. Pengikut atau bawahan memiliki level kebutuhan tertentu, kebutuhan yang termasuk dalam kebutuhan tingkat tinggi, yaitu kebutuhan akan harga diri dan kebutuhan mengaktualisasikan diri. Star follower merupakan pengikut yang penuh energy dan sangat aktif dan berani memberikan alternative solusi pada pemimpin. Oleh karena itu sering kali Star follower dijadikan orang kepercayaan dan menjadi pendamping pemimpin di setiap kesempatan karena kemampuannya. Bagi Star follower, kepercayaan yang dia terima bisa dijadikan jembatan untuk mencapai kesuksesan, melakukan aktualisasi diri dengan cara mengoptimalkan kemampuan untu kemajuan dan perkembangan organisasi.

Di sisi lain, kepemimpinan transaksional, menurut Bass (Locke, 1998), dikatakan sebagai pertukaran imbalanimbalan untuk mendapatkan kepatuhan bawahan. Imbalan yang diberikan bertujuan untuk memenuhi kebutuhan bawahan level rendah atau kebutuhan dasar, ketika pemimpin mampu memenuhinya diharapkan bawahan berupaya maksimal dalam melakukan pekerjaannya.

Dari uraian di atas, dapat dikatakan bahwa kepemimpinan transformasionaltransaksional merupakan kepemimpinan yang mempertimbangkan kekhasan bawahan atau pengikut dengan harapan tujuan yang ditetapkan oleh organisasi dan pemimpin bisa dicapai, dan yang perlu dicatat juga bahwa tidak ada kepemimpinan yang berhasil tanpa didukung oleh pengikut yang cocok dengan kepemimpinan tersebut.

\section{Daftar Pustaka}

Bass, B.M. 1985. Leadership and Performance Appraisal Beyond Expectation. New York : Free Press

Burn, J.M. 1978. Leadership. New York : Harper \& Row

Dessler, G. 1993. Winning Commitment : How to build and Keep a competitive workforce. Singapore ; Mc.Graw-Hill Inc

Emerry, C.R dan Barker, K.J . 2007. The effect of transactional and Transformational Leadership styles on the organizational commitment and job satisfaction of customer contact personnel. Jurnal of organizational culture, Communication and 


\section{Conflict.january}

Levinson, H. 2006. Harry Levinson on the Psychology of leadership. Harvard Business School Publishing Corporation.

Locke , E.A. dan Associates.1997. Essensi Kepemimpinan: empat kunci untuk memimin dengan penuh keberhasilan, Aris Ananda (penerjemah). Jakarta : Mitra Utama

Logomarsino ,R dan Cardona, P . 2003. Relationship among leadership organizational commitment and $O C B$ in Uruguayan Health Institution. University of Nevara
Miner.1992. Industrial Organizational Psychology. New York : Mc.GrawHill

Rifai, V. 2003. Kepemimpinan dan PerilakuOrganisasi. Jakarta : PT Raja Grafindo

Riggio, R.E, Chaleff,I. and Lipman-Blumen. 2008. The art of Followership. San Francisco : Jossey-Bass A Wiley Imprint

Safaria, T. 2004. Kepemimpinan .Yogjakarta: Penerbit Graha Ilmu

Yukl, G. 1998. Kepemimpinan dalam organisasi. Yusuf Udaya (penerjemah), Jakarta: Prehallindo 